\title{
Urban water body recreational development and revitalizing program in Sri Lanka: Public perception and willingness to pay
}

\author{
R. Ratnayake ${ }^{1}$, N. Wickramaarachchi, and P. Wattege, \\ Department of Town \& Country Planning, University of Moratuwa, Sri Lanka
}

\begin{abstract}
Urban water body recreational areas add varied socio- economic and environmental benefits to the urban lives. This study explores public perception and their willingness to pay for open water area recreational development at Sri Jayewardenepura Kotte, Sri Lanka. A total number of 300 questionnaire surveys were carried out with users and non users of the recreational area. The monetary value of urban water front development was gauged by the contingent valuation method using payment card approach. Enjoying peace and relaxation, taking children to play and breath clean air were mentioned as most important aspects of open water body areas. More frequent visits occur to enjoy peace and relaxation, breath clean air and enjoy the natural landscape. Almost all the participants were agreed upon conserving open water body areas in urban settings. Willingness to pay was significantly associated with income and occupation status. It yielded a monthly average payment of Rs. Rs.446.93 per household for another five years time. There were 33 percent of zero bids. Limited budget was the main reason for not willing to pay. This study indicates the applicability of contingent valuation method in valuing economic value of non market goods in developing countries. The findings could assist future open water body development and conservation and argue the need of considering community views and expectations in relevant public spaces and policies. This paper is significant as there is no contingent valuation method study has been carried on water body development in Sri Lanka.
\end{abstract}

Key words: Urban open recreational area, Valuation of Ecosystem, Willingness to pay

\section{Introduction}

Demand for urban ecosystem services is growing everywhere in the world. Rapid urbanization and change of lifestyles require more public open spaces in cities to fulfil different socio, economic and environmental needs of the city population (Wolch, Byme, \& Newell, 2014). Public open spaces provide residents with outdoor recreational activities, contact with nature and enhance the biodiversity in the urban landscape. Ample urban open spaces indicate the livability and the sustainability of the modern cities (Chieura, 2004; Jim \& Chen, 2006). In recent years, open water body development and revitalizing has become a popular feature in the urban fabric of Sri Lanka. Properly designed and managed open water body area can facilitate engagement in the neighbourhood and the environment. Planning of open spaces, therefore need careful consideration of needs and aspirations of people.

Hence acknowledging the importance of public perceptions, planning bodies pay more attention to facilitate designer's perspectives. Further in the legal and planning process in Sri Lanka, public participation is not effectively considered. In order to create effective and sustainable open spaces, it is important to understand perceptions of local

\footnotetext{
${ }^{1}$ Corresponding Author

iD https://orcid.org/0000-0002-8733-9060, https://orcid.org/0000-0003-1371-9754, https://orcid.org/0000-0003-4055-2179

Email address: rangajeewar@gmail.com, naduniwick@gmail.com, premachandra.wattage@port.ac.uk
}

DOI: http://doi.org/10.4038/bhumi.v5i2.30 
people on the development, conservation and their values. The concept of ecosystem services can be used to highlight the importance of preserving and sustainable management of open resources, hence attract the attention of relevant authorities to manage problems in a more efficient and effective manner and implement better policies (Nielsen, Olsen, \& Lundhede, 2007). Valuation of ecosystem services by attaching a monitory value to such services is more effective means of highlighting the importance of these natural resources which are being neglected otherwise (Hanemann, 1994).

This study used stated preference approach to assess the willingness to pay (WTP) of users and local people for recently revitalized open water body in Sri Jayawardenarapura Kotte Sri Lanka (Administrative capital of Sri Lanka). The Stated preference approach is an economic technique to estimate the monetary value of non-economic goods such as greenery, water bodies, and parks. In this family of research approach, Contingent Valuation Method (CVM) has been increasingly used in valuing environmental goods (Rahim, 2008; Lo \& Jim, 2010) including non-use values (Wattage \& Mardle, 2008). Even though more economically valuable natural resources lie in the developing countries, relatively few studies have been carried out in this part of the world (Hadker, Sharma, David, \& Muraleedharan, 1997a). To the best of our knowledge, no CVM study has been carried on water body recreational development in Sri Lanka. To the best of our knowledge there is no other study carried out to estimate the economic value of the open water body recreational area in Sri Lanka.

This paper organized as follows: section 2 provides a brief literature review on studies that used CVM to access WTP for urban ecosystem facilities. The next section discusses the study location and the research method. The design of the questionnaire is presented in detail under the second section. Results of the study are organized under four subsections: response rate and socioeconomic characteristics of respondents, importance and challenges of using urban water bodies, conservation of open water bodies and WTP. Next section summarizes the study findings and develops the discussion. The conclusion of the paper discusses the applicability of economic valuation methods to value non-market goods in developing countries and future prospects in estimating economic value in environmental goods.

\section{Literature review}

Providing high quality urban green spaces have become a key component of urban planning. Providing recreational facilities for city dwellers have been identified as an important aspect of planner's role. Rapid urbanization, the rise of income level, changes of lifestyles and concerns on healthy living has increased the demand for urban open space recreational facilities (Berg et al., 2015). Therefore, many studies have emphasized the importance of accessing the monetary value of intangible and non-market benefits of open urban green spaces (Jim \& Chen, 2006).

Studies assessing the economic value of natural resources such as ecosystem services, biodiversity, wildlife, cultural goods and waste management have increased with the increased awareness of aesthetic, ecological, environmental and public social functions of these resources (Breffle, Morey \& Lodder, 1998; Choi, Ritchie, Papandrea, \& Bennett, 2010; Nielsen, Olsen, \&Lundhede, 2007; 
Noonan, 2003; Shang, Che, Yang, \& Jiang, 2012; Venkatachalam, 2004). In the past, aesthetic or scenic quality of environmental assets was valued using qualitative methods. Some have challenged the traditional method of considering public opinion and showed the advantages of using CVM in the planning process. They criticized the traditional tools of participatory planning approaches as that limits public participation or as a tool that allows planners to justify their projects and priorities only. Qualitative valuation of the environment is difficult to integrate into the assessment procedure (Tyrvainen \& Vaananen, 1998). Such methods have the limitation to provide a universal language to justify the importance of revitalizing and conserving non-market goods.

To address this limitation and to make the planning process systematic, some researchers have suggested applying environmental economic approaches to measure the market value of public goods. By adopting a monetary value to non-market goods provides a standard platform to compare and justify the rationale behind the policy decisions (Jim \& Chen, 2006)). Under this approach CVM has been highlighted as a better way to determine whether the environmental projects are in public interest and whether they need to be continued. The proper cost-benefit analyses can serve as the foundation for planning decisions and investment (Lindsey \&Knaap, 1999, Wattage, et. al., 2000). Several government agencies have commissioned procedures for using CVM in their regulations. In this backdrop, the importance of assessing the economic value of non-market goods have been increasingly used in many countries (Hadker et al., 1997b; Lindsey \& Knaap, 1999, Tyrvainen \& Vaananen, 1998)
This literature review has briefly looked at the contingent valuation studies focusing on urban greenery recreational amenities. Mostly these studies were focused to estimate the economic value of national parks (Bateman \& Langford, 1997; Hadker, Sharma, David, \& Muraleedharan, 1997b). Estimating non-market benefits of an urban park in Spain Salazar and Melendez (2007) reported that the mean WTP is considerably higher for people who live closer to the parks. A study from China revealed that the income has a significant association with the WTP (Jim \& Chen, 2006). Lo and Jim (2010) reported that Hong Kong residents are willing to pay for urban green spaces is significantly associated with age and income. A study from India revealed that despite being a developing country with medium to lowincome, the participants are WTP to preserve environment amenities (Hadker, Sharma, David, \& Muraleedharan, 1997).

It was difficult to find any study conducted to assess the monetary value of open water body development and revitalizing a project. However, assessing the monetary value of recreational amenities in a water body, help the policymakers and planners to understand public views and also the sustainability of the project. In Sri Lanka, it is very rare to find CVM to solicit monetary values of open water bodies may be due to the lack of concern on using public views in the decision-making process. Moreover, open water body development is a recently developed recreation related activity in Sri Lanka. However, it is worthwhile to gauge information on public perceptions and expectations including the monetary value on revitalizing open water bodies. Planners and policymakers can use this information to valuethe land use when allocating the land for different uses. CVM on Diyatha Uyana and 
surroundings are of interest to many people because it is one of the widely used recreational urban waterbody in Sri Lanka.

\section{Study area and methods}

\subsection{Study location-}

Sri Jayewardenepura Kotte

Sri Jayewardenepura Kotte is the legislative capital of Sri Lanka, located $8 \mathrm{~km}$ southeast to the commercial capital of Colombo. During the $15^{\text {th }}$ to $16^{\text {th }}$ centuary, this area used to be the country's kingdom and called as Kotte. Currently, a municipality governs Sri Jayewardenepura Kotte and has developed into an urban area featuring a number of urban characteristics. Sri Jayewardenepura Kotte is a planned city with a number of government building including the

Parliament of Sri Lanka and ministerial buildings. Despite the urban development the area is still contains lagoons, swamps marshy lands and paddy fields.
In terms of the demographic characteristics, this municipality has a population of 107,925 living in an area of $17 \mathrm{~km} 2$. Age distribution of the population shows $70.3 \%$ of the population is in 15-64 year age group while $18.3 \%$ in $0-14$ year age group and $11.4 \%$ of the population over 65 of years.

The research site of Diyatha Uyana and surrounding areas are situated in Sri Jayewardenepura Kotte (see Figure 1). It was established in 2012 under the guidance and close supervision of Urban Development Authority and the Secretary of Defense. The area sits between the Parliament complex and the Diyawannawa Oya. The marshy land on the banks of Diyawannawa Oya has been converted into parks with walking tracks, children's play areas, restaurants and small shops.

It is rare to find studies conducted on the development of Urban Parks in Sri Lanka. However, one study on the motivations and

\section{Case Study Area: Diyatha Uyana and Surrounding}
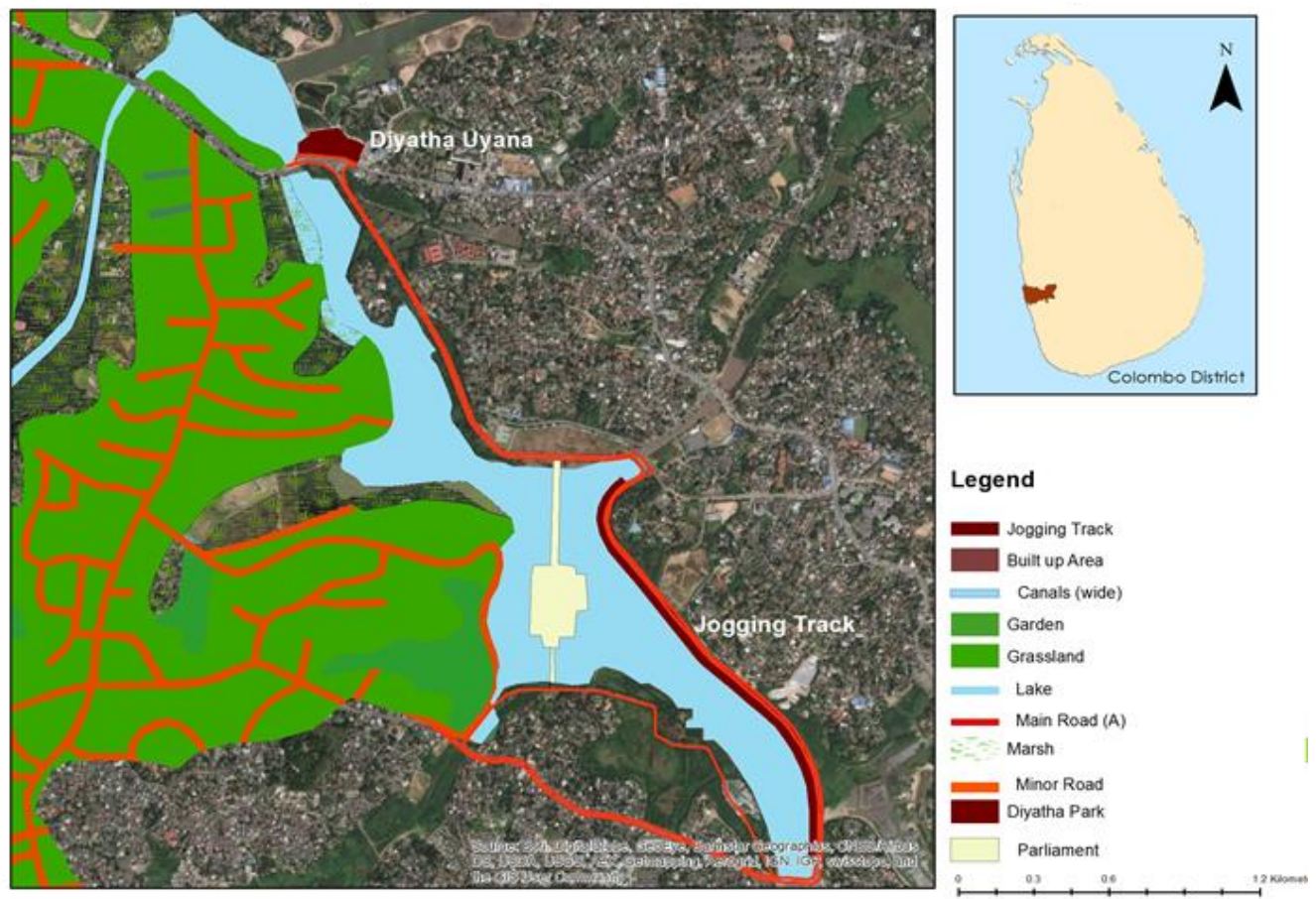

Figure 1: Case study area

Source: Survey Department, Colombo, Sri Lanka, 2010. 
issues of the Diyatha Uyana reports relaxation, contact with nature, contact with family, to do physical exercise and to play with children as the popular motivations to visit the park. On contrary, this research has identified nine issues of using the park. The most popular issues were noisy environment, expansion of population, disturbance to the persons engaged in exercises, distraction to take 3D photos, lack of recourses, effectiveness of strike rules and regulation of the organization, lack of park spaces, lack of signing boards and lack of safety. Even though this study had identified the motivations and changeless it has not explored the participants' view on the value of the park (Pal and KgcpP, 2015). The current study aims to identify the monetary value of the site by engaging with the users and non-users.

\subsection{Questionnaire design}

The current research used CVM to estimate WTP for preservation and management of the open water body recreational area in Diayatha Uyana and surrounding area. User and non-user perspectives and attitudes on the development and conservation of open water bodywas also measured. It was a questionnaire-based approach to assess the economic value of non-market goods. CVM provides three different formats when eliciting monetary value: Dichotomous choice, open-ended, and payment card approaches (Venkatachalam, 2004). Previously, both dichotomous choice and open-ended payment card approaches have been commonly used in assessing the economic value (Lo \& Jim, 2010). However, both methods faced practical limitations. The dichotomous method seeks participants' willingness or unwillingness to pay for a given amount by researchers. Even though this question is easy to understand for the participants it requires a large sample size and also it restricts having an actual preferred value of the respondents. The open-ended method provides the better variation of participants' preferred value. However, it requires participants' understanding of bidding system. Payment card approach has been emerged as a hybrid of these two approaches and has been adopted in recent studies (Jim \& Chen, 2006).

The current study used payment card approach. The dichotomous approach was less applicable with the resource constraints. The open-ended question method is hard to practice with the citizens of Sri Lanka as most Sri Lankan are not familiar with assigning a monetary value to non-market commodities. To overcome these limitations, payment card approach was adopted which provides participants with a direct prompt and also provide the space for respondents to indicate their preferred amount if they are not satisfied with the given choice.

The design of the questionnaire is important in contingent valuation studies (Tyrvainen \& Vaananen, 1998). The questionnaire starts with a brief introduction explaining the aims of the survey. The first section of the questionnaire explored the respondents' level of participation in different activities at Diyatha Uyana and the surrounding area. First, eight groups of questions seek the importance of open water body for the users and non-users in different activities. Next question recorded the frequency of participation in the above eight activities. Final question under the section one explored the challenges when using the open water body.

Section two explored respondents' perceptions on conserving open water bodies. 
The first question asked whether conservation is important for the users and non-users. Next two sets of debriefing questions were used depending on the response to question 4, i.e., Do you think the conservation of open water body is important to you?. If the answer was yes, they have presented a scaling question with eleven statements to rank the importance of conservation open water bodies. The negative respondents were presented a scaling question nine statement to rank the negative effects of conserving open water bodies.

The WTP questions started with a hypothetical statement mentioning the reduction of public open spaces in the Sri Jayewardenepura Municipal council area (See Text Box 1). Respondents were recommended to consider their financial circumstances before filling these questions. The respondents were asked to state their willingness to pay for conservation and development of open water body of a given amount (Rs.1000.00 per month). This amount was selected as an equal average amount of normal monthly fee for a Gymnasium in this area. Then an open-ended question was asked the participants to bid their payment.

After stating their WTP, positive bidders were presented open-ended question to know the motives of their action. Non-positive bidders (Rs 0 ) were presented another openended question to see the rationale behind choosing not to pay for the open water body revitalizing program.

The questionnaire ends with 12 questions gleaning respondents socio-economic characteristics. Such data helped to assertion whether socio-economic status affects willingness to pay.
Text box 1: Hypothetical statement

Research on open space shows that rapid urbanization in your area and reduction of open spaces within the next five years may cause some social and environmental problems. As a remedy to this situation, government is planning to continue the development of urban open water bodies and conservation program to ensure recreational needs of the society. As a citizen you may have to contribute towards this conservation and development effort. It is certain that the money you pay will directly affect how much open water bodies can be resumed and conserved. Before you make a decision, please consider the followings: (a) your household income and expenditure (b) your habits and preferences, and (c) the social and environmental features of the district.

\subsection{Sampling method and data analysis}

A total of three hundred people were adopted for the survey. The stratified sampling method was employed to ensure to capture different groups of people. Ten university students were recruited to conduct the survey in August 2017 on Sunday morning and afternoon. A survey was carried out on the site and also at neighbourhood houses. The data were analyzed using SPSS software. Linear regression models were constructed to identify the factors associated with the stated WTP.

\section{Results}

\subsection{Response rate and socioeconomic characteristics of respondents}

A total number of 300 questionnaires were filled by face to face interviews or by the respondents themselves. Socio-economic profile shows that over half of the respondents (62.0\%) were in 30-49 of age group (Table 1). Fifty-seven percent of respondents have completed their high school education and forty percent have obtained a university or higher degrees. In terms of monthly income, nearly half of the respondents fall within Rs. 50,000 - 100,000 
monthly household income bracket. Fewer respondents indicated over Rs. 300,000 income level. Over one-quarter of participants (27.0\%) reported <Rs. 50,000 household income. Over three-quarters of the respondents indicated they are employed fulltime or part-time basis.

\subsection{Importance and challenges of using urban water bodies}

The survey gathered information on the importance of open water bodies, the frequency of uses and challenges facing by users and non-users. Visits to open water body are induced by different activities. The most important aspect of the open water body is to provide a peace and relaxed atmosphere (Table 2).

Dwellers of Sri Jayewardenepura are now facing lack of open greenery spaces close to Table 1: Demographic profile of the sample

\begin{tabular}{lll}
\hline Socio-economic variables & Categories & Survey \% \\
\hline \multirow{2}{*}{ Age } & $<30$ years & 21.3 \\
& $30-49$ years & 62.0 \\
& $>50$ & 16.7 \\
\hline \multirow{3}{*}{ Monthly household income } & $<$ Rs. 30,000 & 6.0 \\
& Rs.30,000- 49,000 & 21.3 \\
& Rs.50,000-100,000 & 48.3 \\
& Rs. 100,000-300,000 & 22.0 \\
& Rs. $>300,000$ & 2.3 \\
\hline \multirow{3}{*}{ Education } & Primary school & 2.3 \\
& High school & 57.3 \\
\multirow{2}{*}{ Gender } & University & 15.7 \\
& Post Graduate & 24.7 \\
\hline \multirow{3}{*}{ Employment } & Male & 64.3 \\
& Female & 35.7 \\
& Full-Time & 72.3 \\
& Part Time & 6.3 \\
& Unemployed & 9.7 \\
\hline
\end{tabular}

their houses. Therefore, open spaces like Diyatha Uyana and surroundings provide a calming characteristic to the environment. Taking children to play and breathe fresh air was another aspects ranked as important by the participants of the study. Again the lack of open back garden areas in the neighbourhood limits children's activities. And also the busy lifestyles of families restrict children's play activities. These reasons may lead to taking children to an open recreational area few times a week by parents. That increases physical activities as well as social interaction skills of children. Physical exercise and stroll was ranked as the fourth important factor and provides a clear indication of the need for open spaces in highdensity urban areas to support residents' physical well-being.
Enjoy the natural landscape, chat or gather with friends and add an economic value to the area were ranked less important. While away from home was less important probably due to the busy lifestyle. This finding is compatible with Lo and Jim's (2010) study 
on Hong Kong urban greenery. Lastly, biking was least important. This may indicate the less accessibility of separate biking paths to reach the Diyatha Uyana and surrounding parks and also because of the business of the place.

Most frequent visits were occurred to enjoy the peace and relaxation, breath clean air and to enjoy the natural landscape (Table 3). This reflects the users and non-users desire for tranquility in the middle of the busy urban lifestyle.

The analysis evaluated information on challenges of using Diyatha Uyana and surrounding area. This understanding could inform park designing and planning authorities to overcome existing weaknesses of the park. Inadequate parking and sporting facilities were the most mentioned difficulties facing by the participants.

The findings of this study can be useful in proposing open water body development in urban areas to develop advertising campaign, as some (23\%) mentioned of their incapability of finding a park close to their residence. People tend to travel some distances to visit Diyatha Uyana and surroundings as shown in Table 4.

Table 2: Why might open water body be important to you?

\begin{tabular}{lccccccc}
\hline \multirow{2}{*}{\multicolumn{1}{c}{ Categories }} & \multicolumn{9}{c}{ Valid responses \% } & \multirow{2}{*}{ Score } & Rank \\
\cline { 2 - 6 } & SD & D & N & A & SA & & \\
\hline Exercise or stroll & 6.3 & 1.3 & 9.3 & 37.7 & 45.3 & 343 & 4 \\
Breath clean air & 1.0 & 1,0 & 16.3 & 45.0 & 36.7 & 346 & 3 \\
Chat or gather with friends & 3.0 & 3.0 & 18.2 & 44.1 & 31.6 & 292 & 6 \\
Take children to play group & 4.4 & 0.7 & 10.1 & 33.9 & 51.0 & 377 & 2 \\
Biking & 44.3 & 11.1 & 18.9 & 14.5 & 11.1 & -186 & 9 \\
While away time & 7.4 & 4.7 & 22.8 & 43.0 & 22.1 & 202 & 8 \\
Enjoy the natural landscape & 2.7 & 4.7 & 19.0 & 40.0 & 33.7 & 292 & 5 \\
Add an economic value to the area & 6.7 & 9.4 & 18.1 & 35.2 & 30.5 & 219 & 7 \\
Enjoy the peace and relaxation & 0.0 & 1.0 & 7.4 & 33.8 & 57.9 & 444 & 1 \\
\hline
\end{tabular}

$\mathrm{SD}=$ Strongly Disagree, $\mathrm{D}=$ Disagree, $\mathrm{N}=$ Neutral, $\mathrm{A}=$ Agree, $\mathrm{SA}=$ Strongly Agree

Aggregate score is calculated by summing the weights given to $=S D=-2, D=-1, N=0, A=1, S A=2$

Table 3: How often do you participate in the following activities?

\begin{tabular}{|c|c|c|c|c|c|c|}
\hline \multirow[t]{2}{*}{ Categories } & \multicolumn{4}{|c|}{ Valid responses \% } & \multirow[t]{2}{*}{ Score } & \multirow{2}{*}{ Rank } \\
\hline & Never & Rarely & Sometimes & Often & & \\
\hline Exercise or stroll & 19.7 & 13.7 & 29.3 & 37.3 & 553 & 4 \\
\hline Breath clean air & 4.7 & 24.0 & 41.3 & 30.0 & 588 & 2 \\
\hline Chat or gather with friends & 9.7 & 27.4 & 45.5 & 17.1 & 507 & 6 \\
\hline Take children to play group & 21.7 & 12.7 & 29.7 & 35.7 & 537 & 5 \\
\hline Biking & 78.6 & 10 & 9 & 2 & 188 & 8 \\
\hline While away time & 16 & 24.3 & 42.3 & 17 & 480 & 7 \\
\hline Enjoy the natural landscape & 9.3 & 18.3 & 48.7 & 23.3 & 557 & 3 \\
\hline Enjoy the peace and relaxation & 4 & 10.3 & 43.3 & 41.3 & 663 & 1 \\
\hline
\end{tabular}

Another key challenge is finding a suitable parking spaces (28\%) which could have avoided if it was considered at the planning stage of the park.
Under the other category, around $38 \%$ of participants have mentioned maintenance issues as obstacles in using Diyatha Uyana. Fewer trees (27\%), poor sanitation facilities

Aggregate score is calculated by summing the weights given to $=$ Never $=0$, Rarely $=1$, Sometimes $=2$, Often $=3$ 
(19\%) and lack of shade (7\%) were the most mentioned issues under another category. Public concern about their safety has to take consideration as it was mentioned few times under the other category. Some people indicated their concern on gang behaviours, drug problems as a primary concern on their security.

\subsection{Conservation of open water body}

The survey seeks respondents' attitudes towards conserving open water bodies in urban areas. Almost all the participants (99\%) agreed upon conserving open water body areas in their neighbourhood. The motivations behind their attitudes were gauged using eleven debriefing questions as shown in Table 5. Place for relaxation or whiling away from home topped the list. This indicates that the people seek more places to relax in the midst of their busy lifestyles. Many respondents were encouraged to save open areas thinking on environmental benefits.

\section{Willingness to pay}

The survey question 7 was targeted to measure household's WTP to support the development of urban water body and conservation program. In this hypothetical scenario people usually express their WTP monetary value subject to their income and other constraints in their family life. First people were asked whether they are willing to pay a given amount of Rs.1000.00 monthly. About 67 percent $(n=201)$ of respondents showed their support for the program by saying they are willing to pay a price. There was 33 percent of $(n=99)$ zero bids for the WTP. Next, asked them to indicate their perceived maximum amount of payment. The mean WTP of households was Rs.446.93 monthly and which will amount Rs. 5,363.16 per year, suggesting that people are willing to pay a notable amount of money to develop and conserve open water bodies.

Table 4: Challenges facing by people in using Diyatha Uyana and surroundings

\begin{tabular}{lcc}
\hline Categories & Frequent & \% \\
\hline Too far from home & 70 & 23.3 \\
Site area too small & 36 & 12 \\
Inadequate seats & 65 & 21.7 \\
Poor hygiene condition & 32 & 10.7 \\
Too many people & 37 & 12.3 \\
Inadequate sports & & \\
facilities & 78 & 26 \\
Poor landscape quality & 13 & 4.3 \\
Inadequate parking & & \\
spaces & 85 & 28.3 \\
Lighting & 8 & 2.7 \\
None of the above & 25 & 8.3 \\
Other (please specify) & 37 & 12.3 \\
\hline
\end{tabular}


Table 5: Importance of conservation

\begin{tabular}{|c|c|c|c|c|c|c|c|}
\hline \multirow[t]{2}{*}{ Category } & \multicolumn{5}{|c|}{ Valid Responses } & \multirow[t]{2}{*}{ Score } & \multirow[t]{2}{*}{ Rank } \\
\hline & $\begin{array}{c}\text { Not } \\
\text { at all }\end{array}$ & Slightly & Somewhat & Very & Extremely & & \\
\hline $\begin{array}{l}\text { Encourage outdoor } \\
\text { activities }\end{array}$ & 2.0 & 0.7 & 9.4 & 42.3 & 45.0 & 972 & 2 \\
\hline $\begin{array}{l}\text { Increase property value of } \\
\text { the area }\end{array}$ & 3.0 & 4.9 & 16.8 & 45.5 & 29.1 & 781 & 10 \\
\hline Enhance aesthetic quality & 2.7 & 5.3 & 11.7 & 40.7 & 38,3 & 912 & 5 \\
\hline Present wild life habitat & 15.3 & 19.0 & 21.7 & 22.0 & 20.7 & 633 & 11 \\
\hline Good for public health & 3.0 & 10.7 & 14.7 & 45.3 & 25.3 & 832 & 9 \\
\hline $\begin{array}{l}\text { Strengthen community } \\
\text { sprit }\end{array}$ & 0.7 & 3.3 & 14.3 & 46.0 & 34.3 & 922 & 4 \\
\hline Reduce air pollution & 3.3 & 8.0 & 18.3 & 39.3 & 29.7 & 844 & 8 \\
\hline Purify air and environment & 0.7 & 8.3 & 16.3 & 39.0 & 34.3 & 886 & 7 \\
\hline Cools the atmosphere & 2.0 & 7.7 & 13.0 & 41.0 & 35.0 & 890 & 6 \\
\hline $\begin{array}{l}\text { Allow more contact with } \\
\text { nature }\end{array}$ & 1.3 & 5.0 & 12.7 & 38.7 & 41.0 & 931 & 3 \\
\hline $\begin{array}{l}\text { Place for relaxing or } \\
\text { whiling away from home }\end{array}$ & 0.3 & 3.0 & 7.0 & 4.0 & 54.7 & 1013 & 1 \\
\hline
\end{tabular}

Average scores $=-0=$ Not at all, 1=Slightly, 2= Somewhat, 3= Very, 4= Extremely Important

Multiple linear regression model was applied to estimate factors affecting for respondent's WTP (Table 6). All the respondents who did not answer the question were removed before running the program.

As indicated in $F$ test (or global test), the entire model is highly significant at $\alpha=0.01$ (or 1\%) level. Among the other independent variables Income and job are significant at $\alpha$ $=0.01$ level. The gender variable is also significant at $\alpha=0.05$ level. For every oneunit change in gender, the log odds of admission (versus non-admission) increases by 0.002 .The expected sign for all independent variables chosen are positively contribute towards the WTP values. Variables of age and being a member of an environment group are however not significant.

\subsection{Motivations to Pay / Not Pay}

Under question 9 it was aimed to understand the motivations behind the willingness to pay or not willingness to pay (Table 7). It is important to get these ideas rather neglecting the forces behind the action. First, participants were asked to mention why would they pay that amount?

Findings indicate peoples' need for such palaces providing a green light for the policy makers and planners to build more open areas in urban settings. Citizens' understanding of their responsibility in protecting environmental features is a good sign for the sustainability of this program. 
Table 6: Linear regression model for the respondent's WTP for development and conserve of urban water bodies.

Coefficients $^{\text {a }}$

\begin{tabular}{lrrrrrr}
\hline \multicolumn{1}{c}{ Model } & \multicolumn{2}{c}{ Unstandardized Coefficients } & $\begin{array}{c}\text { Standardized } \\
\text { Coefficients }\end{array}$ & \multicolumn{1}{c}{$\boldsymbol{t}$} & Sig. \\
& \multicolumn{1}{c}{$\beta$} & & Std. Error & $\beta$ & & \\
\hline 1 Constant & -2760.915 & 1022.412 & & -2.700 & .008 \\
Income & 244.858 & 78.926 & .239 & 3.102 & .002 \\
Age & 23.024 & 233.569 & .008 & .099 & .922 \\
Environmental Group & 66.832 & 76.040 & .065 & .879 & .381 \\
Job & 184.061 & 68.509 & .199 & 2.687 & .008 \\
Gender & 257.977 & 121.875 & .162 & 2.117 & .036 \\
\hline
\end{tabular}

a. Dependent Variable: Willingness to Pay Maximum Amount

Table 7: Why would you pay the amount in question 8 ?

\begin{tabular}{lc}
\hline Categories & Sample agreed \\
\hline This program is important for us & 114 \\
It is our responsibility to protect our open spaces & 111 \\
I want to contribute to a good cause & 55 \\
Other & 12 \\
\hline
\end{tabular}

Table 8: Why you didn't contribute to this program

\begin{tabular}{lc}
\hline Categories & Sample agreed \\
\hline This program is not important to us & 9 \\
I am on a limited budget & 26 \\
I do not think this program would be effective & 14 \\
I do not think that I should be responsible for this program & 11 \\
Current system of development and management is adequate & 9 \\
I do not support any new government programs & 12 \\
\hline
\end{tabular}

Next, participants were asked the reasons behind their choice of not willing to pay for the water body development (Table 8).

This finding is compatible with the earlier findings of this study. It also shows that individual's income as a significant factor behind their decisions of WTP.

\section{Discussion}

The survey results suggest people's strong desire in developing and conserving open water bodies in urban areas. This finding can be used to justify the planning decisions and also expenditure used upon developing urban water body recreational areas in cities.
The importance (Table 2) and the occurrence of visiting (Table 3) open water bodies showed an overlapping ranking indicating people's high desire for having an attachment with the natural environment. The three top ranks for visiting open water bodies were related to acquiring environmental benefits. This may due to the reduction of open places in Sri Jayewardenepura municipal area with the rapid urbanization. With the busy lifestyle and the reduction of open spaces in a neighbourhood may have restricted the attachment with nature recently, however, the community and open water bodies have started to re-generate this behaviour. This behaviour pattern is somewhat related to the western people's motivations of visiting open 
green spaces. However, this is different from the findings from Hong-Kong (Jim \& Chen, 2006). The changes of Sri Jayewardene Pura land use show the reduction of water bodies and marshy land. According to 2010 data of land use patterns show that this area consists $10.4 \%$ marshy land and $2.1 \%$ lakes which are very sensitive with eco-diversity. The survey results in emphasis the need of developing and conserving open spaces in urban areas.

No parking places is a common issue facing by the users of urban facilities such as open recreational areas. The increase of car ownership and peaceful environment after the civil war has accelerated people's mobility. The increase of public transportation would reduce the pressure on providing parking spaces. Lack of availability of open spaces seems to be an issue for the participants of the survey. This suggests the need of upgrading public open spaces in urban areas. There can be neighbourhood small potential places which have been neglected because of the more attractive urban recreational areas. Localizing some open recreational areas in neighbourhoods will reduce the pressure on city level places like Diyatha Uyana. Future urban recreational planning can use landscape ecological approach to maximize the spatial, social and environmental benefits (Jim \& Chen, 2006).

Overall, lack of infrastructure facilities was mentioned as obstacles in using Diyatha Uyana and surrounding recreational area. A requirement of more sporting facilities indicates people's increasing consciousness on health and wellbeing. This reflects the answers given to question one (Table 2) and two (Table 3). Respondents ranked exercise and stroll at the fourth most important function and also as the fourth in visiting order. With the busy and unhealthy lifestyle urban dwellers are now becoming more aware of the need of physical activities.

\subsection{Willingness to pay to use open water body}

The findings of this study show the WTP for open water body recreational areas is high among the users and non-users of this study. It is significant for a developing country with people who have limited experience in applying a monetary value to eco-service systems. Currently, there is no entrance fee for open water body recreational areas in the country. Therefore, this research indicates that even people use these facilities for free for years in-return they have a moral feeling to pay for the conservation of eco-service systems. The mean value of this study is half of the amount usually people pay for an indoor physical exercise center in Sri Lanka.

This study found that income and job had a significant positive influence on WTP. This is more compatible with some studies around the world regardless of the economic development of the country (Jim \& Chen, 2006). This indicates that still Sri Lankan people consider recreational and amenity enjoyment as a superior good. The findings revealed that the moral and ethical considerations are not considered in valuing environmental amenities by the participants of this study. This should be given more consideration when making policy decisions in future regarding enforcing fees to use natural resources. However, Tyrvainen and Vaanane's study on the urban forest in Finland revealed that the income does not have any significant impact on people's willingness to pay. This study shows the positive attitudes of people's moral and ethical consideration on the environment. This is a promising indication of protecting 
ecological systems, and to stop pollution in the country.

\section{Conclusion}

Sri Lankans have little experience of conducting $\mathrm{CV}$ surveys. This needs to be considered when analyzing the data of the current study. The idea of applying a monetary value for the environmental good seems to be unusual for some participants. As a new concept, it took time for the participant to understand the hypothetical situation. Some people might have thought of an actual payment and could have given a lower amount regardless of their actual willingness. Therefore, careful consideration should be given in drafting the survey and should give special emphasis to highlight the hypothetical situation in the survey.

Adopting a monetary value for eco-service systems could provide a justification for policy makers and planners. Development plans can be incorporated with public views and monetary value. By understanding people's motivation and incorporating them into planning decisions in return would attract more support in maintaining and conserving rather neglecting eco-service systems, thinking or criticizing them as a government project.

Finally, the current study provides a green light in conducting more $\mathrm{CV}$ studies for valuing not only water body recreational developments in the country but also for the other environmental goods such as forests, biodiversity, eco-tourism and water resources. More and more economic valuations on urban open spaces would influence the policy and planning decision in the country. Therefore, it is important to conduct this kind of studies and then the people also would use to adopting an economic value for the environmental goods.

\section{References}

Bateman, I. J., \& Langford, I. H. 1997, Non-users' willingness to pay for National Park: An application and critiqueof thecontingent valuation method. Regional Studies, 31(6), 571.

Berg, M.V. D., Wendel-Vos, W., Proppel, M., Kemper, H., Mechelen, W. V., \& Maas, J. 2015,Urban Forestry \& Urban Greening, 14(4), 806-816.

Breffle, W. S., Morey, E. R., \& Lodder, T. S. 1998, Using contingent valuation to estimate a neighbourhood's willingness to pay to preserve undeveloped urban land. Urban Studies, 35(4), 715-727.

Chieura, A. (2004). The role of urban parks for the sustainable city. Landscape and Urban Planning, 68(1), 129-138.

Choi, A. S., Ritchie, B. W., Papandrea, F., \& Bennett, J. 2010,Economic valuation of cultural heritage sites: A choice modelling approach. Tourism Management, 31, 213-220.

Hadker, N., Sharma, S., David, A., \& Muraleedharan, T. R. 1997, Willingness-to-pay for Borivli National Park: evidence from a Contingent Valuation. Ecological Economics, 27, 105127.

Hanemann, W. M. 1994, Valuing the environment through contingent valuation. The Journal of Economic Perspectives, 8(4), 19-43. 
Jim, C. Y., \& Chen, W. Y. 2006, Recreation-amenity use and contingent valuation of urban greenspaces in Guangzhou, China. Landscape and Urban Planning, 75, 81-96.

Lindsey, G., \& Knaap, G. 1999, Willingness to pay for urban greenway projects. Journal of American Planning Association, 65(3), 297-354.

Lo, A. Y., \& Jim, C. Y. 2010, Willingness of residents to pay and motives for conservation of urban green spaces in the compact city of Hong Kong. Urban Forestry \& Urban Greening, 113120.

Noonan, D. 2003, Contingent valuation and cultural resources: A meta-analytic review of the literature. Journal of Cultural Economics, 27, 159-176.

Nielsen, A. B., Olsen, S. B., \& Lundhede, T. 2007, An economic valuation of the recreational benefits associated with nature-based forest management practices. Landscape and Urban Planning, 80, 63-71.

Pal, O., \& Kgcp, W. (2015). Motivations and issues: Diyatha Uyana urban park visitors in Sri Lanka. International Journal of Scientific and Research Publications, 5(8), 1-7.

Rahim, K. A. 2008, Contingent Valuation Method. Paper presented at the Regional Training Workshop: Economic Valuation of the Goods and Services of Coastal Habitats, Thailand

Salazar, S. d. S., \& Menendez, L. G. 2007, Estimating the non-market benefits of an urban park: Does proximity matter? Land Use Policy, 24, 296-305.

Shang, Z., Che, Y., Yang, K., \& Jiang, Y. 2012, Assessing Local Communities' Willingness to Pay for River Network Protection: A Contingent Valuation Study of Shanghai,China. International Journal of Environmental Research and Public Health, 9, 3867-3887.

Tyrvainen, L., \& Vaananen, H. 1998, The economic value of urban forest amenities: An application of the contingent valuation method. Landscape and Urban Planning, 43, 105-118.

Venkatachalam, L. 2004, The contingent valuation method: A review. Environmental Impact Assessment Review, 24(1), 89-124.

Wattage, P., Smith, A., Colin, P., McDonald, A. and Kay, D. (2000) Integration of Environmental Impact, Contingent Valuation Methodology And Cost Benefit Analysis: Empirical Evidence For An Alternative Perspective. Impact Assessment and Project Appraisal journal. Vol. 18, No: 1, March.

Wattage, P. and Mardle, S, (2008) Total economic value of wetland conservation in Sri Lanka identifying use and non-use values, Journal of Wetland Ecology and Management, Volume 16, Pages 359-369.

Wolch, J. R., Byme, J., \& Newell, J. P. 2014, Urban green space, public health, and environmental justice: The challenge of making cities 'just green enough' Landscape and Urban Planning, 125, 234-244. 